\title{
A retrospective study of haemophagocytic lymphohistiocytosis in children in a tertiary care hospital in Eastern India
}

\author{
*Suparna Guha ${ }^{1}$, Gautam Guha² \\ Sri Lanka Journal of Child Health, 2018; 47: 219-222
}

\begin{abstract}
Introduction: Haemophagocytic lymphohistiocytosis $(\mathrm{HLH})$ is a rare disorder that is being increasingly reported in children from the Indian subcontinent.
\end{abstract}

Objective: To describe the profile of HLH in children in a tertiary care hospital in Eastern India.

Method: This is a retrospective study of all children diagnosed to have HLH from March 2015 to August 2016 and admitted to the paediatric department of Vivekananda Institute of Medical Sciences, India. The case records of the children with HLH were analysed.

Results: Fifteen children were diagnosed with HLH during the study period. All were secondary cases, infection being the predominant cause. More than $50 \%$ needed some immune modulation in the form of steroids/intravenous immunoglobulin. Two succumbed to complications.

Conclusions: All 15 cases of HLH were secondary (acquired). Eighty percent of the cases were secondary to infection.

DOI: http://dx.doi.org/10.4038/sljch.v47i3.8542

(Key words: Haemophagocytic lymphohistiocytosis, infections, steroid, intravenous immunoglobulin, Eastern India)

\section{Introduction}

Haemophagocytic lymphohistiocytosis (HLH) is a rare disorder that is being increasingly reported in children from the Indian subcontinent. HLH

${ }^{1}$ Vivekananda Institute of Medical Sciences, Kolkata India, ${ }^{2}$ Nil Ratan Sircar Medical College and Hospital, India

*Correspondence: drs68guha@gmail.com

(Received on 08 September 2009: Accepted after revision on 27 October 2017)

The authors declare that there are no conflicts of interest

Personal funding was used for the project.

Open Access Article published under the Creative

Commons Attribution CC-BY (c) (i) involves the mononuclear phagocytes and is characterized by activation and proliferation of histiocytes leading to a cytokine storm which causes dysfunction of various organs ${ }^{1}$. It is a macrophage related hyper-inflammatory disorder presenting as prolonged fever and a sepsis like syndrome ${ }^{2,3}$. It is of two types, primary (familial) and secondary (acquired). The latter is usually secondary to infections, rheumatological disorders or malignancy. Primary HLH affects very young children and has a high mortality. Both varieties of HLH can be preceded by infections and require molecular genetic techniques for differentiation ${ }^{3,4}$.

\section{Objective}

To describe the profile of HLH in children in a tertiary care hospital in Eastern India.

\section{Method}

This is a retrospective study of all children diagnosed to have HLH from March 2015 to August 2016 and admitted to the paediatric department of Vivekananda Institute of Medical Sciences, India. Only children meeting the diagnostic criteria of HLH-2009 protocol $^{5}$ (Table 1) were included in the study.

The case records of the children with HLH were analysed and the following data collected: age at presentation, gender, family history, clinical and laboratory features, course of illness and ultimate outcome. For peripheral blood counts and biochemistry, nadir and peak values were noted. In one patient, primary immune deficiency was thought of and a complete work up was done including lymphocyte subsets, immunoglobulin levels, oxidative burst test (dihydrorhodamine test for chronic granulomatous disease) and CD11, CD18 (to rule out leucocyte adhesion deficiency).

A male neonate (history of severe intrauterine growth retardation, term delivery) presented with cholestasis and hepatosplenomegaly at 14 days of life. Cytomegalovirus (CMV) polymerase chain reaction $(\mathrm{PCR})$ was positive in urine. One week after admission he developed HLH. Such an early onset led us to do a genetic analysis to rule out familial HLH. 


\section{Table 1: HLH diagnostic criteria 2009}

1. Molecular diagnosis of haemophagocytic lymphohistiocytosis $(\mathrm{HLH})$ or X-linked lymphoproliferative syndrome (XLP).

2. Or at least 3 of 4 :

- Fever

- Splenomegaly

- Cytopenias (minimum 2 cell lines reduced)

- Hepatitis

3. And at least 1 of 4 :

- Haemophagocytosis

- Increased ferritin

- Increased sIL2R $\alpha$ (age-based)

- Absent or very decreased NK function

4. Other results supportive of HLH diagnosis:

- Hypertriglyceridaemia

- Hypofibrogenaemia

- Hyponatraemia

\section{Results}

Fifteen children were diagnosed with HLH over a period of 1.5 years. The ages ranged from 3 weeks to 11 years. Females outnumbered males. There was no history of consanguinity in any of the families. In our study, no primary /familial case was identified.
In one case of congenital CMV infection, early occurrence of $\mathrm{HLH}$ prompted us to do a genetic analysis (MUNC/Perforin) but no abnormality was detected. All the cases were secondary HLH and infection (Table 2 ) was the commonest cause (13 out of 15).

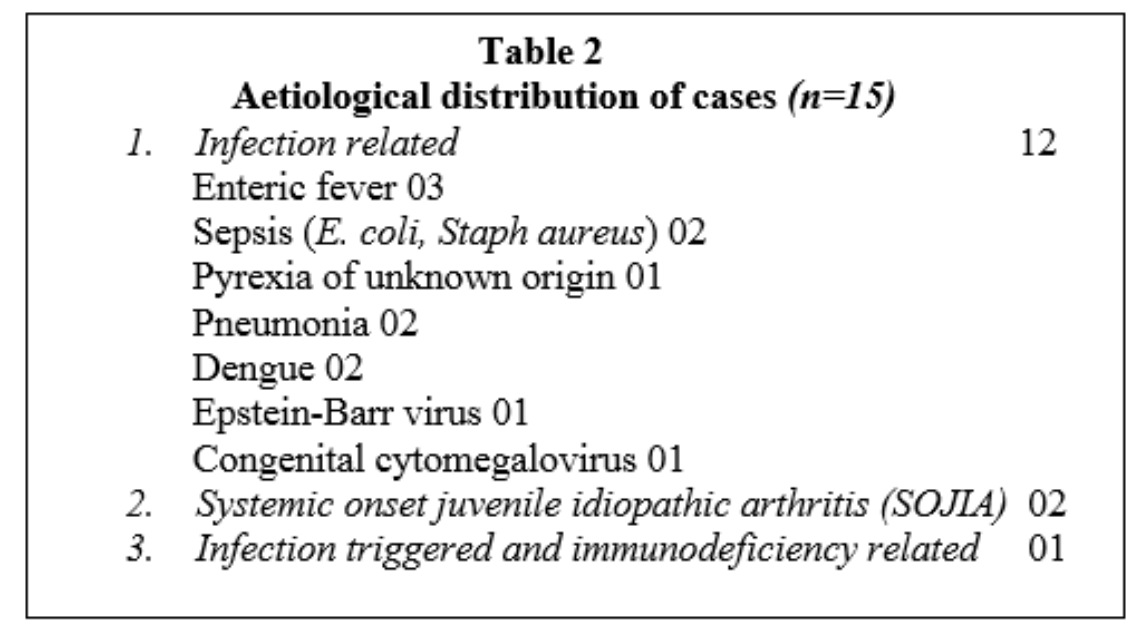

The 2 cases of systemic onset juvenile idiopathic arthritis (SOJIA) presented with macrophage activating system (MAS) at the onset. There was a single case of primary immune deficiency, leucocyte adhesion defect (LAD1) where HLH occurred secondary to Burkholderia cepacia septicaemia. Bacterial infections outnumbered viral. Enteric fever was the initial presentation in 3 cases; 2 children initially presented with pneumonia, having fever and progressive tachypnoea. There was a girl with a history of choledochal cyst who presented with acute pancreatitis. Initial conservative management brought temporary relief but on the $10^{\text {th }}$ day of admission she developed pancytopenia with increasing ferritin. Dengue virus was isolated in 2 cases and Epstein-Barr virus (EBV) in one.

Interval from onset of symptoms to diagnosis of
HLH varied between 1-3 weeks. The clinical features of HLH are enumerated in table 3.

Table 3: Clinical features of $\mathrm{HLH}(n=15)$

\begin{tabular}{|l|c|}
\hline \multicolumn{1}{|c|}{ Clinical feature } & Number (\%) \\
\hline Fever & $15(100.0)$ \\
\hline Rash & $07(46.7)$ \\
\hline Hepatosplenomegaly & $15(100.0)$ \\
\hline Respiratory distress & $06(40.0)$ \\
\hline Lymphadenopathy & $03(20.0)$ \\
\hline Hepatic failure & $01(06.7)$ \\
\hline Bleeding & $02(13.4)$ \\
\hline Neurological involvement & $04(26.8)$ \\
\hline
\end{tabular}

All 4 cases with neurological involvement had cerebrospinal fluid (CSF) analysis done which showed lymphocytic preponderance with elevated protein levels. 
The laboratory features of HLH are enumerated in table 4.

Table 4: Laboratory features of $\mathrm{HLH}$

\begin{tabular}{|l|c|}
\hline \multicolumn{1}{|c|}{ Laboratory feature } & No. (\%) \\
\hline Low fibrinogen & $12(80.0)$ \\
\hline High triglyceride & $13(86.7)$ \\
\hline Raised liver enzymes & $14(93.3)$ \\
\hline $\begin{array}{l}\text { Haemophagocytosis in bone } \\
\text { marrow }\end{array}$ & $08(53.3)$ \\
\hline Fall in ESR & $07(46.7)$ \\
\hline Hyponatraemia & $08(53.3)$ \\
\hline
\end{tabular}

Bone marrow aspiration could be done in 12 out of 15 cases of which 8 showed haemophagocytosis. In more than $50 \%$ of cases, serum ferritin, which was initially $>2000 \mathrm{ng} / \mathrm{ml}$, gradually showed a declining trend and they survived. Three children showed an initial serum ferritin $>5000 \mathrm{ng} / \mathrm{ml}$ and of these 2 succumbed. There was no evidence of malignancy in any patient. These children received supportive therapy in the form of intravenous antibiotics and blood products, where necessary.

Regarding the outcome of the 13 with infective aetiology, treatment of the primary infection could abate /halt the process in 4 cases. Immune modulatory therapy, in the form of intravenous immunoglobulins (IVIG) /steroids, was needed in 9 cases. None of the patients needed aggressive chemotherapy. Two cases succumbed, the patient with congenital CMV having severe disseminated coagulopathy and the patient with LAD losing the battle to hepatic failure.

\section{Discussion}

HLH can occur as a familial /genetic disorder with an autosomal recessive inheritance or as a sporadic or acquired disorder ${ }^{1}$. Both forms can be triggered by infections or immunological events. It is observed in children and adults of all ages. In our series the median age of affection was 4 years, similar to other Asian studies ${ }^{6}$.

In our series comprising 15 cases of HLH, 13 were secondary to infection. In a study by Srinivas et al, infection was the cause in around $50 \%$ of adult patients, $56 \%$ being secondary to viruses, the commonest being dengue ${ }^{7}$. A similar observation was made by Ramachandran et al who also showed dengue virus to be the commonest infective agent causing HLH in a study of 43 hospitalised children from South India ${ }^{8}$. However, in our study, among the infective aetiologies identified, bacteria were commoner (3 salmonella, 1 E.coli, 1 Staphylococcus aureus 1 Burkholderia cephacia). Viruses were isolated in 3 cases and in 3 no aetiological agent could be identified.
The common mode of presentation was persistent fever, hepatosplenomegaly, falling blood counts and hyperferritinaemia. Regarding the outcome, out of the 15 cases, 11 needed immune modulation in the form of IVIG/steroid. The 2 SOJIA cases responded to methylprednisolone and one needed oral cyclosporine. In those with infective aetiology, 9 needed dexamethasone. It was started at $10 \mathrm{mg} / \mathrm{m}^{2}$, gradually tapered and stopped within 4-6 weeks. Contrary to traditional treatment, a full 8 week course of HLH-2004 protocol was not needed. This similar successful short term use of steroid has been demonstrated in a study by Kodan $\mathrm{P}$ et $a l^{9}$. Regarding the factors determining prognosis and outcome, serum ferritin played an important role. In the 2 cases which succumbed, initial ferritin was $>5000 \mathrm{ng} / \mathrm{ml}$. In the survivors, decline in ferritin, rise in $\mathrm{Hb}$, platelets and improvement in clinical profile were observed within 1 week of initiation of therapy.

All the criteria may not be present initially. A decline in the cell counts, a rise in serum ferritin in the backdrop of deteriorating clinical scenario should alert the clinician regarding an evolving HLH.

\section{Conclusions}

- All 15 cases of HLH were secondary (acquired).

- Eighty percent of the cases of HLH were secondary to infection.

\section{References}

1. Farquhar J, Clairpaux A. Familial haemophagocytic reticulosis. Archives of Disease in Childhood 1952; 27:519-25. https://doi.org/10.1136/adc.27.136.519 PMid: 13008468 PMCid: PMC1988563

2. Henter JI. Horne A, Arico M, Egeler RM, Filipovich AH, Imashuku S, et al. HLH2004 : Diagnostic and therapeutic guidelines for haemophagocytic lymphohistiocytosis. Paediatric Blood Cancer 2007; 48:124-31.

https://doi.org/10.1002/pbc.21039

PMid: 16937360

3. Fisman DN. Haemophagocytic syndromes and infection. Emerging Infectious Diseases 2000; 6:601-8. https://doi.org/10.3201/eid0606.000608 PMid: 11076718 PMCid: PMC2640913

4. Janka GF. Haemophagocytic syndromes. Blood Reviews 2007; 21:245-53. 
https://doi.org/10.1016/j.blre.2007.05.001

PMid: 17590250

5. Filipovich AH. Haemophagocytic lymphohistiocytosis (HLH) and related disorders. Available from:

http://asheducationbook.hematologylibrar y.org/content/2009/1/127.full\#sec-4

6. Ariffin H, Lum SH, Cheok SA, Sekhar K, Ariffin WA, Chan LL et al. Haemophagocytic lymphohistiocytosis in Malaysian children. Journal of Paediatrics and Child Health 2005; 4:136-9.

https://doi.org/10.1111/j.14401754.2005.0 0564.x

PMid: 15790325

7. Rajagopala S, Singh N. Diagnosing and treating haemophagocytic lymphohistiocytosis in the tropics: Systemic review from Indian subcontinent. Acta Med Acad. 2012; 41:161-74. https://doi.org/10.5644/ama2006-124.49

PMid: 23331391
8. Ramachandran B, Balasubramanian S, Abhishek N, Ravikumar KG, Ramanan A. Profile of haemophagocytic lymphohistiocytosis in children in a tertiary care hospital in India. Indian Paediatrics 2011; 48(1):31-5. https://doi.org/10.1007/s13312-011-00202

9. Kodan P, Chakrani M, Pavan R, Bhat P. Haemophagocytic lymphohistiocytosis secondary to infection: A tropical experience. Journal of Postgraduate Medicine 2015; 61:112-5. https://doi.org/10.4103/0022-3859.150904 PMid: 25766345 PMCid: PMC4943449 